\title{
A Case of Hydatid Cyst with Primary Paraspinal Muscle Involvement
}

\author{
Primer Paraspinal Kas Tutulumu Olan Bir Kist Hidatik Olgusu
}

\section{(D) Halil Ibrahim Bekdemir, (D) Mehmet Paşa* \\ Şemdinli State Hospital, Clinic of Physical Medicine and Rehabilitation, Hakkari, Turkey *Kars Harakani State Hospital, Clinic of Radiology, Kars, Turkey}

\section{To the Editor;}

A 41-year-old female patient was admitted to our clinic with a 3-month history of back pain. The pain was mechanical and there was no concomitant numbness or neuropathic pain such as tingling. The patient had no history of trauma, surgery, chronic illness or infection, and had not benefited from pain relief and myorelaxant drugs. On the physical examination, there was seen to be forward posture and tenderness in the paravertebral area of the back. Active myofascial Pain syndrome could not be detected. Sensory and motor functions were normal in the upper extremity and deep tendon reflexes were normoactive. A direct radiograph of the cervical and thoracic region revealed flattening of the cervical lordosis and an increase in thoracic kyphosis. In addition, mild degenerative changes were observed. The patient, who was followed-up with recommended exercise therapies to correct postural disorder, presented again after 1 month because of increased pain. Magnetic resonance imaging (MRI) of the back area was performed for further examination. At the level of the C7-T1 vertebrae, a lesion with a mass of approximately $3 \times 2 \mathrm{~cm}$ was localized at the midline. A cystic lesion showing hypointensity on T1-weighted sequences and hyperintense septation on T2-weighted sequences was diagnosed as hydatid cyst (Figure 1, 2). Biochemical analysis revealed no leukocytosis and no eosinophilia. CRP was normal. The indirect hemagglutination test for the diagnosis of hydatid cyst was positive. Abdominal ultrasonography and conventional chest radiographs were requested to rule out possible liver or lung involvement. As no pathology was detected in the liver and the lungs, the patient was diagnosed with hydatid cyst with primary muscle involvement. The patient was referred to the Neurosurgery Clinic for surgical treatment and cyst excision surgery was performed. Albendazole 200 mg 2x1 treatment was given for six months after surgery. No new focus or recurrence was observed during follow-up.

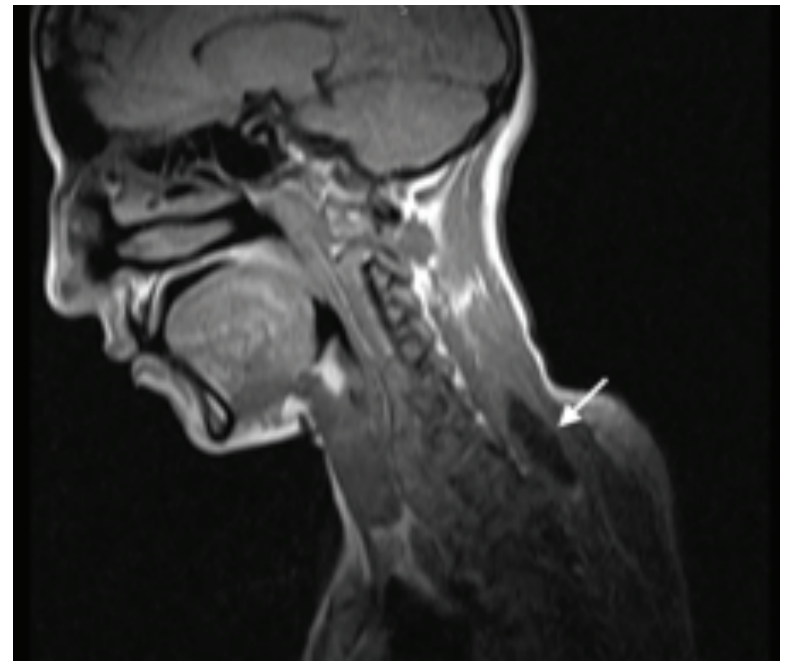

Figure 1. Cystic lesion showing hypointensity on T1-weighted sequences

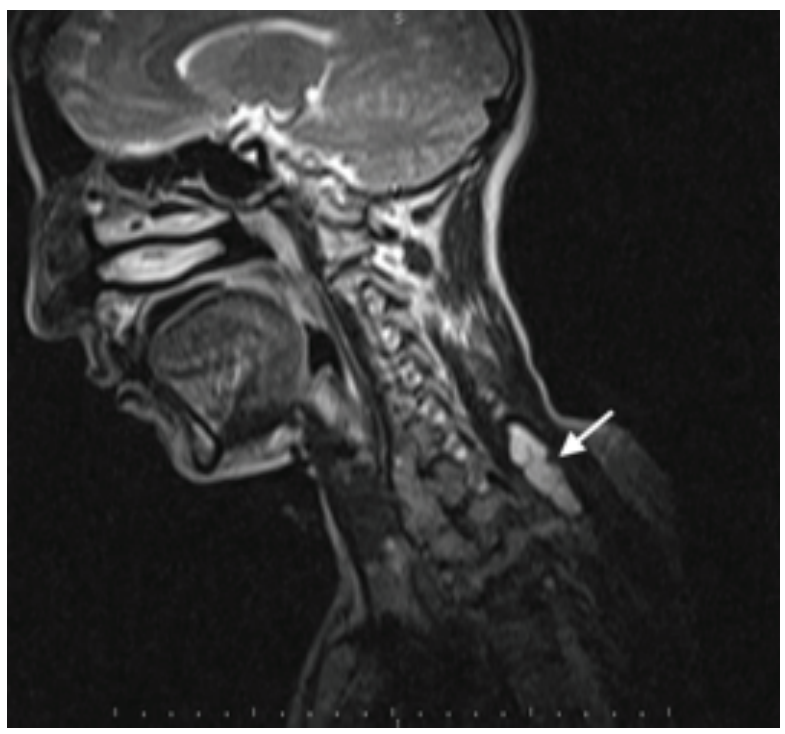

Figure 2. Hyperintense septation on T2-weighted sequences

Address for Correspondence/Yazışma Adresi: Halil ibrahim Bekdemir MD, Şemdinli State Hospital, Clinic of Physical Medicine and Rehabilitation, Hakkari, Turkey Phone: +90 5454060262 E-mail: hibekdr@gmail.com ORCID ID: orcid.org/0000-0001-6333-4014 Received/Geliş Tarihi: 01.03.2019 Accepted/Kabul Tarihi: 19.06.2019 
A hydatid cyst is a parasitic infection caused by the larval stage of Echinococcus granulosus and Echinococcus multilocularis, usually involving the liver, lungs, and brain (1). Echinococcosis has a worldwide distribution and causes health problems in endemic countries such as Australia, Argentina, Africa, the Middle East and the Mediterranean region (2). Hydatid disease rarely affects soft tissues even in endemic areas, and skeletal muscle involvement is extremely rare, with a reported prevalence of $0.5-4.7 \%$ (3). The pathogenesis of muscle involvement is not clearly understood. While some authors claim that it is through direct implantation, most authors believe the embryo can reach the muscles from the systemic circulation after leaving the intestine and passing through two filters: the liver and the lungs (4).

Hydatic cysts usually occur in liver and the lungs, but may localise in any area of the body (4). Since muscle involvement of hydatid disease is rare, our knowledge is limited to case series. Gedik et al. (4) presented a 20-year-old male patient with paravertebral hydatid cyst. Bagcier et al. (3) diagnosed a hydatid cyst in the gastrocnemius muscle of a 40-year old male patient. Both patients underwent surgical excision and medical treatment as in the current patient, and none have relapsed $(3,4)$. Saad et al. $(5)$ presented three hydatid cysts with psoas muscle involvement and Tyagi and Garg (2) reported a hydatid cyst in the brachialis muscle. Bilgic et al. (6) presented a case with paraspinal muscle involvement but used the puncture, aspiration, injection, re-aspiration technique instead of surgery. Musculoskeletal hydatid cyst diagnosis is clinically and radiologically difficult as it resembles a soft tissue tumor. Ultrasonography, computed tomography and MRI have a valuable role in the radiological diagnosis and follow-up of hydatid disease (3). Hydatid cyst should be considered in the differential diagnosis of soft tissue tumors, especially in areas where hydatid cyst is endemic. In addition, in the differential diagnosis of back pain resistant to medical treatment, muscle involvement of hydatid cyst should be considered.

Keywords: Cyst, back pain, magnetic resonance imaging Anahtar Kelimeler: Kist, sırt ağrısı, manyetik rezonans görüntüleme

\section{Ethics}

Peer-review: Externally peer-reviewed.

\section{Authorship Contributions}

Surgical and Medical Practices: H.I.B., Concept: H.I.B., M.P., Design: H.I.B., M.P., Data Collection or Processing: H.I.B., M.P., Analysis or Interpretation: H.I.B., M.P., Literature Search: M.P., Writing: H.I.B.

\section{References}

1. Çalbıyık M, Sayar AÜ. Hydatid cyst of the spine with paraspinal and extradural location: a report of three cases and review of the literature. Middle Black Sea J Health Sci 2017;20-5.

2. Tyagi DN, Garg DN. Primary Intramuscular Hydatid Cyst within Brachialis Muscle: A Case Report and Review of Literature. IOSR J Dent Med Sci 2014;13:23-7.

3. Bagcier F, Onac O, Alkan Melikoglu M. Hydatid Cyst Presenting with Mass That Localized in the Cruris Region. Turk J Parasitol 2016;40:54-5.

4. Gedik E, Girgin S, Akay H, Korkmaz Ö. PRIMER HYDATID CYST IN PARAVERTEBRAL MUSCLE. Eur J Gen Med 2007;4:143-6.

5. Saad H, Hamdi A, Gargouri R, Zouari K, Sghaier MS, Balti MH, et al. "Hydatic cyst of the psoas muscle. Apropos of 3 cases." Ann Chir 1990;44:299-301.

6. Bilgic S, Kose O, Sehirlioglu A, Safaz I, Ozkan H. Primary paraspinal hydatid cyst treated with puncture, aspiration, injection and re-aspiration (PAIR) technique: a case report. Eur Spine J 2009;18 Suppl 2:165-7. 